\title{
Obituary
}

\section{Arthur James Dalzell Ward}

Dr. A. J. Dalzell Ward, Chief Medical Officer of the Health Education Council, who died on March 3, 1976 at the age of 61, was educated at Kings College and Charing Cross Hospital, London. After qualifying in 1937 he held various appointments in Kent and London hospitals. During the second world war he joined the R.A.M.C. and served in Europe and the Far East rising to the rank of Lieutenant-Colonel.

From 1947 to 1952 he worked in the Public Health Service. In 1952 he became a full-time specialist in health education and in 1958 Chief Medical Officer of the Central Council for Health Education, transferring to the equivalent post when the Health Education Council took over in 1968. He served on many committees and was a prolific writer. One of his recent contributions was the revised edition of the 'Textbook of Health Education'. For many years he edited the Health Education fournal and he was an

\section{R. V. C. Robinson, M. D.}

Many British physicians will be sad to learn of the death of Vail Robinson in Baltimore in April, 1976. He was especially well known to that large group of doctors who were Fellows in Medicine under Professor J. E. Moore at the Johns Hopkins Hospital in the late $1940 \mathrm{~s}$ and $1950 \mathrm{~s}$. Vail was a permanent member of the staff of Medicine I and his knowledge and experience of syphilis, particularly congenital syphilis, was well known throughout the United States of America. He was a keen and able teacher and made some excellent films of patients with syphilis, as well as a very complete set of teaching tapes and slides.

He belonged to the well known trio of Pop, Harry, and Vail. These three members of the Robinson family were a semi-permanent part of the Baltimore assistant editor of the Medical Officer. He was also an accomplished, clear, and concise speaker.

$\mathrm{He}$ was especially interested in sex education and in education on the sexually transmitted diseases. He promoted research into both subjects and latterly played an important part in research into the value of STD education and contact tracing. He was also interested in the training of contact tracers.

Dr. Dalzell Ward was a keen supporter of the Medical Society for the Study of Venereal Diseases and read a number of papers to the Society. He was also present at the formation of the British Federation against the Venereal Diseases, and as the representative of the Health Education Council had an important role in the work of the Federation. As an individual he was courteous, kindly, and always helpful. He will be sadly missed by a host of friends and colleagues.

R. N. Thin medical scene, and the father, Pop, lived to a great old age and was remembered with affection all over the world. Vail was a great admirer of the late Earl Moore and before he died was able to pay a special and personal tribute to his former chief by organizing the Earl Moore Memorial Conference at the Johns Hopkins Hospital to which some British physicians were invited and which was an unqualified success.

Vail built up a large practice in dermatology in Baltimore, but his greatest interest lay in venereal diseases and he was at his best when he was demonstrating the physical signs of a case of syphilis to students. Physicians with his extensive knowledge of the disease are now becoming rare throughout the world and his skills and wisdom will be greatly missed.
R. D. Catterall 